\title{
Strange Flowers
}

\author{
Amir Adam Tarsha ${ }^{1}$
}

Received: 18 May 2015 / Accepted: 24 June 2015 / Published online: 30 July 2015

(C) Academic Psychiatry 2015

\section{Strange Flowers}

Her brain is

scorched terrain.

Today rain will fall on the dust and steam will rise from the blackened slopes.

\section{Spring 1976, Eau Claire, WI}

Inpatient Unit B

Insistent light:

she pulls the covers over her face and

tells the men to please please please,

for the love of God,

leave.

She has suffered and survived

her first break.

Tectonic plates converged, and suddenly her thoughts, once nimble and purposeful, were encased in ash.

Did the bodies casted in Pompeii

ever shake their natural shackles?

No says Alice, no no no.
Alice, the doctor is being so very patient, won't you just answer his questions? Won't you just eat your toast? Won't you at least show us your face?

It's a beautiful day.

The land is raw and singed, but the high clouds have gathered again and will soon open over the ridge.

Alice,

show us your face.

Today rivers of soot

will snake between the bare trees,

and in time,

lichen will form on the rocks,

strange flowers

will dot the scape.

Uncover your face, Alice.

Let the light fall upon the

mountainside,

give the blooms

a fighting chance.

Amir Adam Tarsha

atarsha@med.miami.edu

1 University of Miami Miller School of Medicine, Miami, FL, USA 